\title{
Veterans Administration
}

National Cancer Institute

\section{Source}

National Cancer Institute. Veterans Administration. NCI Thesaurus. Code C17239.

A government-run comprehensive benefit system for veterans. 